\title{
STRATEGIC MECHANISMS OF REGULATING THE EUROPEAN INTEGRATION DEVELOPMENT OF AIR TRANSPORT IN UKRAINE
}

\author{
Serhii Smerichevskyi ${ }^{1}$, Svitlana Gura²
}

\begin{abstract}
The purpose of the paper is to substantiate the strategic mechanisms for regulating the European integration development of air transport in Ukraine. Methodology. The study is based on the imperatives of European integration development of air transport of Ukraine, defined in the Association Agreement between the European Union and the European Atomic Energy Community and their member states, on the one part, and Ukraine, on the other part. Quantitative research is based on the analysis of the volume and structure of Ukraine's foreign trade in air transport services, calculation of the export-import coverage ratio, determination of the share of transport and air transport services in aggregate services in total foreign trade, including with the EU. Results of the paper consist in assessing the impact of the external environment on the European integration development of the Ukrainian aviation transport. The conclusion was reached on its turbulence, complexity and contradiction, while the advantageous geographical location and strategic positions of Ukraine in the region were determined as the main favorable factors. The research also singles out the following negative signs of the external environment: declining competitiveness of the Russian-Asian lanes for domestic air carriers, localization of air services in connection with hostilities in the East of Ukraine; restriction of air traffic in the context of preventive measures to combat the spread of coronavirus infection; insufficient material and technical base: lack of funding, outdated technologies, low level of innovation, environmental friendliness, safety, insufficient quality of transport services, limited social benefits; aimed at ratification of the CAA Agreement between Ukraine and the EU, as well as the draft Aviation Transport Strategy of Ukraine. The present research also identified such negative effects of COVID-19 on the development of air transport, as: a significant decrease in air passenger transport services and airlines' revenues, a decrease in the rating of world aviation, termination and bankruptcy of a number of airlines and airports due to air traffic restrictions. It determined the place of air transport services in the system of foreign economic trade in services with the EU countries, and developed measures to increase them. Practical implications consist in the elaboration of the main strategic guidelines for the development of aviation: introduction of a simplified procedure for implementing the provisions of EU legislation into the legislation of Ukraine; ensuring environmental safety and energy saving of civil aviation facilities; innovative renewal of aircraft fleet and reduction of their harmful impact on the environment through the introduction of the latest technologies; settlement of issues relating to the establishment of airport charges for the servicing of aircraft and passengers at Ukrainian airports; development of airport infrastructure; creation of multimodal cargo complexes; approximation of SAAU and European Commission requirements to certification systems in the areas of primary airworthiness, airworthiness maintenance and maintenance of aircraft and its components; expansion of Ukraine's voluntary participation in the program of compensation and reduction of carbon dioxide emissions from international aviation within the CORSIA program, introduction of administrative procedures for monitoring emissions by operators of civil aircraft on international flights under the MRV standards. Value/originality. The present research substantiates strategic foundations of the institutional transformations of the development of aviation transport in the context of the European integration choice of Ukraine and the transition to monovectorality, elimination of defects of dependence on the trajectory of the preceding traffic and polyvectorality. It also proposes legal, policy, investment and infrastructure integration mechanisms.
\end{abstract}

Key words: strategic mechanisms, regulation, European integration development, air transport, Ukraine.

JEL Classification: L10, L93, O11, O19, O29, R48

\footnotetext{
Corresponding author:

${ }^{1}$ National Aviation University, Ukraine.

E-mail: s_f_smerichevsky@ukr.net

ORCID: $\bar{h}$ ttps://orcid.org/0000-0003-2102-1524

${ }^{2}$ National Aviation University, Ukraine.

E-mail: s_f_smerichevsky@ukr.net

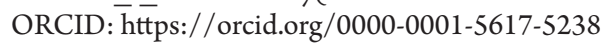




\section{Introduction}

The current trend of the national economy, including aviation transport, is its European integration development as a process of changing the structure, composition of elements and functions of individual socio-economic systems in the course of moving along the vector of European civilizational choice. The main trends in the development of Ukraine's aviation transport market are in line with the world ones, but are characterized by high risks in the external environment, and airlines are seen as entities, interacting with the market as an external crosscutting environment (Savych, Shkoda, 2020). For many of them, the level of risk is critical, partly due to the COVID-19 pandemic.

One of the signs of the development of the aviation industry of Ukraine is the dependence on the trajectory of the preceding traffic. Air transport was rapidly developing in the USSR in the second half of the previous century, but it was characterized by the following negative signs: systematic disruption of flights, incomplete loading of aircraft, non-compliance with scheduled transport, poor quality of passenger services, inadequate service of inter-farm airfields, which on a regular basis reduced economic efficiency (Gorban, 2015).

The presence or absence of a polyvectorality has also a significant impact on the aviation development. The European integration choice of Ukraine requires the implementation of transformational changes in infrastructure capacity in the context of increasing transport capacity in the European region (Butko, Ivanova, 2016). This leads to far-reaching changes in the quantity and quality of the aviation market based on the principles of sustainable development and environmental safety in the long term on the basis of EU directives. In this context, the purpose of the paper is to justify strategic mechanisms for regulating the Euro-Integration development of Ukrainian aviation transport.

\section{Imperatives of European integration development of air transport}

The imperatives of European integration development of air transport of Ukraine are defined by the Association Agreement between the European Union and the European Atomic Energy Community and their member states, on the one part, and Ukraine, on the other one.
The integration of the national transport system into the Trans-European Transport Network is an important part of the Agreement. The transport component of the Association Agreement is provided by its norms (Figure 1), contained in Sections IV, V, Chapter 7 and Annexes XXXII and XXXIII thereto. Implementation of the transport component of the Association Agreement will allow to solve the following tasks: to achieve compatibility of transport systems on the basis of EU directives and technical regulations; to eliminate administrative, technical, border and other obstacles to transport connections; to provide innovative renewal of technical equipment and transport fleet; to modernize and integrate the infrastructure of road, rail, sea, river, air transport; to increase safety on transport; to develop the regional transport network of the Eastern Partnership, connected with TEN-T (Trans-European Transport Network).

Common Aviation Area (CAA) agreements between Ukraine and the EU were initialed in 2013, but its signing has been postponed due to the weak progress of our country in implementing the components of the Association Agreement in the field of air transport. The formation of the $C A A$ provides for the conclusion and implementation of bilateral air services agreements between Ukraine and EU member states, which aim to liberalize the conditions of regular air services, remove restrictions on the list of designated airlines, departure/destination and number of flights. The principles of $C A A$ are the identity of the rules in the following areas of aviation: flight safety, aviation safety, certification, air traffic management, environmental protection, consumer protection, computer ticket booking systems, social norms. The unification of the air transport markets of Ukraine and the EU will promote a more efficient use of the air transportation market, development of the transit potential of Ukraine, efficient distribution of cargo and passenger flows (Yanchuk, 2010).

The action plan for preparation for the implementation of the $C A A$ of Ukraine with the EU and its member states was approved by the order of the Cabinet of Ministers of Ukraine dated 08.02.2017 No. 88-p17. For its implementation, the "General Rules of Flights in the Airspace of Ukraine" Aviation Rules of Ukraine were adopted, approved by the joint Order of State Aviation Administration of Ukraine (SAAU) 


\begin{tabular}{|c|c|c|}
\hline Structural elements & & The main content \\
\hline $\begin{array}{l}\text { Section IV "Trade } \\
\text { and Trade-Related } \\
\text { Issues" }\end{array}$ & 디 & $\begin{array}{l}\text { liberalization of the market of transport services of the EU } \\
\text { member states, creation of preconditions for mutual access to } \\
\text { the market for road, rail and inland water transport, as well as } \\
\text { air transport }\end{array}$ \\
\hline $\begin{array}{l}\text { Section V "Economic } \\
\text { and Sectoral } \\
\text { Cooperation" } \\
\text { (Chapter } 7 \\
\text { "Transport") }\end{array}$ & 4 & $\begin{array}{l}\text { development of sustainable national transport policy, sectoral } \\
\text { strategies for road, rail, river, sea and air transport, accession to } \\
\text { international transport organizations and agreements; scientific } \\
\text { and technical cooperation and exchange of information; } \\
\text { promotion of the use of intelligent transport systems and } \\
\text { information technology }\end{array}$ \\
\hline Annex XXXII & & $\begin{array}{l}\text { a list of EU directives and regulations to which Ukraine } \\
\text { undertakes to gradually approximate its legislation in } \\
\text { accordance with the established deadlines, including in the } \\
\text { field of air transport - the conclusion of the Common } \\
\text { Aviation Area Agreement, which provides for the } \\
\text { implementation of } 64 \text { acts of EU legislation }\end{array}$ \\
\hline Annex XXXIII & ᄃ & $\begin{array}{l}\text { intermodality, development of a multimodal transport network } \\
\text { connected to the } T E N-T \text { Trans-European Transport Network }\end{array}$ \\
\hline
\end{tabular}

Figure 1. Formalization of the content of the Association Agreement transport component

Source: International document (2014)

and the Ministry of Defense of Ukraine dated 06.02.2017 No. 66/73. They are based on SAAU Regulations: No. 1178/2011 - for civil aviation flight crews (order dated 20.07.2017 No. 56518), No. 139/2014 - for aerodrome certification (order dated 06.11.2017 No. 84919), No. 965/2012 - for air operation (order dated 05.07.2018 No. 68220). The lack of adoption of a number of laws and regulations aimed at ensuring the effective and simplified implementation of the provisions of European Union legislation in Ukraine is hampering the implementation of the "Action Plan for the Preparation of Implementation of the CAA of Ukraine with the EU", among which are: draft Laws of Ukraine "On Features of State Regulation of Air Carriers' Activities Related to the Carriage of Passengers and/or Cargo by Air", "On Amendments to the Air Code of Ukraine Concerning the Adoption of Aviation Rules of Ukraine".

Environmental factors also have a significant impact on the European integration development of Ukraine's air transport.

\section{The impact of the external environment on the European integration development of air transport in Ukraine}

Under current conditions, the external environment of Ukraine's air transport is turbulent, complex and contradictory. The main favorable factor for the European integration development of Ukraine's air transport is its favorable geographical position and its strategic position in the region. On the one hand, the signing of the Association Agreement with the EU opens wide opportunities for its development related to the establishment of the CAA. On the other hand, firstly, political-military conflicts have reduced the competitiveness of the Russian-Asian direction for domestic air carriers; caused the localization of air communication in connection with hostilities in the East Ukraine; secondly, there are air traffic restrictions in the context of preventive measures to combat the spread of coronavirus infection, which significantly reduce the volume of air transport services and airline revenues; thirdly, insufficient material and technical base: lack 
of funding, outdated technologies, low level of innovation, environmental friendliness, safety, insufficient quality of transport services, limited social benefits. The institutional environment is also unfavorable due to the delay in the adoption of legal acts of Ukraine aimed at ratification of the CAA Agreement between Ukraine and the EU, and the draft Aviation Transport Strategy of Ukraine (Ministry of Infrastructure of Ukraine, 2021).

The overall development disincentive for the EU and Ukraine was the COVID-19 pandemic, which gradually reduced air mobility in the EU and peaked in April 2020, when the number of flights in the euro-zone fell by almost 90\% (Nižetić, 2020). Unlike passenger transport, the impact of the pandemic on air freight traffic was less negative. Moreover, there has been an increase in the supply of medical equipment and medicines to counteract the spread of coronary virus infection and its consequences.

The pandemic has caused great damage to global aviation due to rating downgrade, closure and bankruptcy of a number of airlines and airports in consequence of air traffic restrictions, loss of revenue and more. Resumption of operations requires airlines to reduce operating costs, increase attention to the health of passengers and their anti-epidemic protection, the implementation of international safety standards (Dube, Nhamo, Chikodzi, 2021).

The generalization of the state of the external environment allows us to assess its impact on the development of the market of air transport services and the competitiveness of domestic carriers.

\section{The place of air transport in the system of foreign economic trade in services with $\mathrm{EU}$ countries}

The entry into force of the Association Agreement and the liberalization of the visa regime for Ukraine have given new impetus to the development of foreign economic trade in Ukraine's air transport services with EU countries. During 2016-2018, passenger traffic between Ukraine and Europe has doubled, the activities of more than 10 regional airports have been resumed, and the airports of Odesa and Dnipro have been reconstructed. In Ukraine, such new trends have emerged that are characteristic of the European aviation market: an increase in the number of passenger transports and the volume of passenger turnover, and an increase in the loyalty of the population to the aviation transport services (Holovanova, Levin, 2019).

In 2016, there was a change in the trend of export activity of domestic air transport companies from downward to upward, so this year can be considered a bifurcation point. Ukraine has a positive balance of trade in services with all countries and with EU countries. In 2020, it amounted to 5957889,6 thsd. USD and 1459009,0 thsd. USD correspondingly (Table 1).

This conclusion also applies to the segment of transport services and air transport services. In the total value of exports of services, transport services to all countries of the world and the EU countries account for $43.7 \%$ and $25.4 \%$, respectively, and air transport services $-16.3 \%$ and $31.3 \%$, respectively.

Exports of transport services to all countries of the world are 4.81 times higher than imports to the EU - by 1.98 times. The difference in import coverage over aviation exports is not significant, amounting to 2.54 and 2.10 respectively for the world and the EU. This indicates a greater concentration of exports of air transport services in European markets compared to markets in other countries. The share of imports of transport services in the aggregate imports of services to all countries of the world and European countries differs slightly and makes up $19.5 \%$ and $19.6 \%$ respectively, and the share of all countries by the imports of air transport services $(31.0 \%)$ slightly exceeds the share of European countries (29.4\%).

EU countries are important counterparties of Ukraine in the field of purchase and sale of air transport services. The share of their exports to EU countries in total exports of services (42.53\%) is almost twice the export ratio of transport services $(22.17 \%)$ and is more than the share of total services (38.1\%). This indicates a higher export competitiveness of domestic air transport services compared to other modes of transport and other services. The opposite situation is observed in the sphere of import activity. Ukraine is less dependent on imports of air transport services from EU countries - their share is $51.35 \%$ against $54.04 \%$ for transport services and $53.68 \%$ for aggregate services. However, Ukrainian air carriers are relatively less competitive than the European ones, as the share of imports of air transport services exceeds the share of exports by $8.82 \%$. The outlined situation can be defined as the relative loss of export potential of air transport services against the background of increasing import capacity of 
Vol. 2 No. 1, 2021

Green, Blue \& Digital Economy Journal

Table 1

Structure of foreign trade by types services with EU countries in 2020

\begin{tabular}{|c|c|c|c|c|c|c|c|c|}
\hline \multirow[b]{2}{*}{ Types of services } & \multicolumn{3}{|c|}{ Exports } & \multicolumn{3}{|c|}{ Imports } & \multirow[b]{2}{*}{$\begin{array}{l}\text { Balance, } \\
\text { thsd. USD }\end{array}$} & \multirow[b]{2}{*}{$\begin{array}{l}\text { Exports/ } \\
\text { Imports, } \\
\text { coef-ficient }\end{array}$} \\
\hline & thsd. USD & $\begin{array}{l}\% \text { of } \\
2019\end{array}$ & $\begin{array}{c}\% \text { of the } \\
\text { total volume, } \\
\text { section }\end{array}$ & thsd. USD & $\begin{array}{l}\% \text { of } \\
2019\end{array}$ & $\begin{array}{c}\% \text { of the } \\
\text { total volume, } \\
\text { section }\end{array}$ & & \\
\hline & \multicolumn{7}{|c|}{ All countries } & \\
\hline Total & 11167050,7 & 71,5 & 100,0 & 5209161,1 & 75,0 & 100,0 & 5957889,6 & 2,14 \\
\hline Transport services & 4880294,3 & 53,6 & 43,7 & 1013616,1 & 65,0 & 19,5 & 3866678,2 & 4,81 \\
\hline \multirow[t]{2}{*}{ Air transport services } & 796113,8 & 56,1 & 16,3 & 313910,3 & 41,4 & 31,0 & 482203,5 & 2,54 \\
\hline & \multicolumn{7}{|c|}{ EU countries } & \\
\hline Total & 4255102,5 & 95,2 & 100,0 & 2796093,5 & 75,0 & 100,0 & 1459009,0 & 1,52 \\
\hline Transport services & 1081841,9 & 79,5 & 25,4 & 547717,4 & 59,9 & 19,6 & 534124,5 & 1,98 \\
\hline \multirow[t]{2}{*}{ Air transport services } & 338610,1 & 55,9 & 31,3 & 161190,5 & 33,1 & 29,4 & 177419,6 & 2,10 \\
\hline & \multicolumn{7}{|c|}{ Specific weight, \% (EU countries/All countries) } & \\
\hline Total & 38,10 & - & - & 53,68 & - & - & 24,49 & - \\
\hline Transport services & 22,17 & - & - & 54,04 & - & - & 13,81 & - \\
\hline Air transport services & 42,53 & - & - & 51,35 & - & - & 36,79 & - \\
\hline
\end{tabular}

Source: State Statistics Service of Ukraine (2021)

the domestic market. It is based on both objective factors related to the institutional and economic regulation of the international aviation market in the context of European integration and subjective factors, primarily because the national air carriers are less competitive in terms of quality, price of services and air safety.

\section{Strategic guidelines for regulating the European integration development of air transport in Ukraine}

The effectiveness of the European integration development of air transport in Ukraine requires the adoption of a program document presented by the Aviation Transport Strategy of Ukraine for the period up to 2030. We propose to define the following main strategic guidelines: introduction of a simplified procedure for implementing the provisions of EU legislation into the legislation of Ukraine; ensuring environmental safety and energy saving of civil aviation facilities; innovative renewal of aircraft fleet and reduction of their harmful impact on the environment through the introduction of the latest technologies; settlement of issues related to the establishment of airport fees for the maintenance of aircraft and passengers at the airports of Ukraine; development of airport infrastructure; creation of multimodal cargo complexes; approximation of SAAU and European Commission requirements to certification systems in the areas of primary airworthiness, airworthiness maintenance and maintenance of aircraft and its components; expansion of Ukraine's voluntary participation in the program of compensation and reduction of $\mathrm{CO}_{2}$ emissions from international aviation within the CORSIA program (Carbon Offsetting Scheme for International Aviation), introduction of administrative procedures for monitoring emissions by civil aircraft operators on international flights under $M R V$ (Monitoring, reporting and verification) standards.

Strategic objectives of state regulation of air transport development (Brusakova, 2020) are: ensuring the growth of services and approval of methods for assessing their effectiveness, innovative infrastructure development, strengthening the international competitiveness of domestic carriers, increasing the transit potential of Ukraine through the development of formats of powerful international hub airports, balancing revenues and expenditures in the industry, providing tax preferences for manufacturers of aircraft and spare parts for its maintenance, establishing state control over the formation of tariff policy for air travel, introduction of corporate governance practices at state aviation enterprises, implementation of international (aviation, economic, environmental, information, life, etc.) air safety standards; monitoring their compliance and strengthening the responsibility for violations.

Strategic mechanisms for strengthening the competitiveness of air transport enterprises are a set of forms and methods "aimed at achieving their long-term competitive advantage, based on the principles of flexibility and adaptability to 
changes in the environment, innovation, system and situationality" (Vasylenko, 2015). The main mechanisms for strengthening the international economic competitiveness of Ukraine's air transport are:

firstly, integration and legal issues related to the development of CAA between Ukraine and EU member states in terms of implementation of safety standards, international certification, implementation of quality management systems, compliance with environmental regulations, consumer protection, provision of electronic services to passengers, adoption corporate governance codes and relevant amendments to the Air Code of Ukraine, etc.;

secondly, program mechanisms related to the adoption of the draft Aviation Transport Strategy of Ukraine for the period up to 2030: renewal of aircraft fleet on an innovative basis, reduction of their harmful impact on the environment, introduction of new air traffic technologies, energy saving, energy efficiency, etc.;

thirdly, investment and infrastructure mechanisms related to the reconstruction of airports in order to increase their capacity, improve the quality of passenger and cargo transportation services, create modern terminals and multimodal cargo complexes. The inclusion of Ukraine's leading airports in the Indicative Investment Plan for the Development of the Trans-European Transport Network TEN-T will help attract funds from European investors for their development.

Among the important guarantees of strengthening the international economic competitiveness of Ukraine's air transport we can point out the improvement of the competitive environment in the domestic aviation market in all its segments (air transport services, airport services, ground handling of aircraft), support of fair competition standards, prevention of abuse of monopoly power and discrimination, provision of open and transparent access to the aviation market and its infrastructure. Factors for improving the institutional environment are currency liberalization and increasing the investment attractiveness of the aviation market of Ukraine.

\section{Conclusions}

We formalized the content of the transport component of the Association Agreement between Ukraine and the EU as follows: liberalization of the transport services market of the EU
Member States, ensuring mutual access to it; national transport policy; development of sectoral strategies; accession to international transport organizations and agreements; scientific and technical cooperation; implementation of EU directives and regulations; development of a multimodal transport network.

Analysis of the volume and structure of Ukraine's foreign trade in air transport services has allowed to establish the following features: the presence of its positive balance; greater concentration of exports in European markets compared to markets in other countries; proportionality of imports with a slight advantage of all countries; the increase in the share of exports of air transport services to the EU in total exports of services is almost double compared to the share of exports of transport services and is lower in the share of total services, indicating higher export competitiveness of domestic air transport services compared to other modes of transport and other services; the situation is different in the sphere of import activity, as Ukraine is less dependent on the import of air transport services from the EU countries as compared to the transport and aggregate services.

It has been proved that the strategic determinant of the aviation market development should be the strengthening of the international competitiveness of Ukrainian air carriers, as the excess of imports of air transport services over exports represents the relative loss of export potential of air transport services as the import capacity of the domestic market grows. It is based on both objective factors related to the institutional and economic regulation of the international aviation market in the context of European integration and subjective factors, first of all, because national air carriers are less competitive in terms of quality and price of services and air safety.

The present research offers basic provisions of the Aviation Transport Strategy of Ukraine for the period up to 2030 as a program document designed to increase the efficiency of European integration development of air transport in Ukraine. It also singles out the following strategic tasks of the state regulation of the development of air transport and the mechanisms of their implementation: integration-legal, program, investment-infrastructural.

The purpose of further research is to substantiate the institutional and economic mechanisms for regulating the development of cargo air transport. 


\section{References:}

Brusakova, O. V. (2020). Sutnist ta osoblyvosti derzhavnoho rehuliuvannia $\mathrm{v}$ haluzi aviatsiinoho transportu [The essence and features of state regulation in the field of air transport]. Bulletin of Kharkiv National University of Internal Affairs, 2: 104-115.

Butko, M., \& Ivanova, N. (2016). The modern trends of infrastructure development. Baltic Journal of Economic Studies, 2(3), 37-41. doi: https://doi.org/10.30525/2256-0742/2016-2-3-37-41

Dube, K., Nhamo, G., \& Chikodzi, D. (2021). COVID-19 pandemic and prospects for recovery of the global aviation industry. Journal of Air Transport Management, 92: 102022. doi: https://doi.org/10.1016/ j.jairtraman.2021.102022

Gorban, A. (2015). Problems of the efficiency increasing of transportation by air of Ukrainian SSR (1960-1980). Baltic Journal of Economic Studies, 1(2), 40-44. doi: https://doi.org/10.30525/22560742/2015-1-2-40-44

Holovanova, M. A., \& Levin, D. M. (2019). Intehratsiia Ukrainy do yevropeiskoho povitrianoho prostoru yak faktor pidvyshchennia konkurentospromozhnosti krainy [Ukraine's integration into European airspace as a factor in increasing the country's competitiveness]. Bulletin of Khmelnytsky National University. Economic sciences, 5: 78-84.

International document (2014). Association Agreement between the European Union and the European Atomic Energy Community and their member states, of the one part, and Ukraine, of the other part. Available at: https://zakon.rada.gov.ua/laws/show/984_011\#Text (accessed 19 April 2021).

Ministry of Infrastructure of Ukraine (2021). Aviation transport strategy of Ukraine for the period up to 2030 (project). URL: https://mtu.gov.ua/files/Dok_PROEKT/\%D0\%90\%D0\%B2\%D 1\%96\%D0\% B0\%D 1\% 86\%D 1\%96\%D0\%B9\%D0\%BD \%D 0\%B $0 \% 20 \% \mathrm{D} 1 \% 82 \% \mathrm{D} 1 \% 80 \% \mathrm{D} 0 \% \mathrm{~B} 0 \% \mathrm{D} 0 \% \mathrm{~B}-$ D\%D 1\%81\%D0\%BF\%D0\%BE\%D1\%80\%D1\%82\%D0\%BD\%D0\%B0\%20\%D 1\%81\%D1\%82\%D1\%80 \%D0\%B0\%D1\%82\%D0\%B5\%D0\%B3\%D1\%96\%D1\%8F\%202030.docx (accessed 19 April 2021).

Nižetić, S. (2020). Impact of coronavirus (COVID-19) pandemic on air transport mobility, energy, and environment: A case study. International Journal of Energy Research, 44: 10953-10961. doi: https://doi.org/10.1002/er.5706

Savych, O., \& Shkoda, T. (2020). Trends of air transportation market development in Ukraine. Innovative Marketing, 16(2): 29-39. doi: http://dx.doi.org/10.21511/im.16(2).2020.03

State Statistics Service of Ukraine (2021). Foreign trade in services. Available at: http: //www.ukrstat.gov.ua (accessed 19 April 2021).

Vasylenko, V. A. (2015). Formuvannia mekhanizmu upravlinnia konkurentospromozhnistiu aviatsiinykh pidpryiemstv $\mathrm{v}$ suchasnykh umovakh [Formation of a mechanism for managing the competitiveness of aviation enterprises in modern conditions]. Problems of system approach in economy, 52: 136-142.

Yanchuk, M. B. (2010). Osnovni napriamky derzhavnoi polityky shchodo intehratsii aviatsiinoho sektoru Ukrainy v systemu transievropeiskykh transportnykh merezh [The main directions of the state policy on the integration of the aviation sector of Ukraine into the system of trans-European transport networks]. Bulletin of Transport Economics and Industry, 30: 145-148. 